УДК 328:004 (477)

https://doi.org/10.34142/24130060.2019.19.2.06

\title{
ПОПУЛЯРИЗАЦІЯ ЕЛЕКТРОННОГО УРЯДУВАННЯ В УКРАЇНІ ЯК ЗАПОРУКА ЕФЕКТИВНОСТІ ПРОЦЕСУ ДЕМОКРАТИЗАЦІЇ: ПОЛІТИКО-КУЛЬТУРНИЙ РАКУРС
}

\author{
Б.Ю. Куц \\ Національна академія державного управління при Президентові України
}

Стаття присвячена виявленню специфіки популяризачії електронного урядування в Україні. Зазначається, щу важливою компонентою електронного урядування $\epsilon$ електронна демократія, завдяки якій постає можливість уникнення надмірної бюрократизації в системі органів влади, наближення влади до громадян иляхом задоволення їхніх потреб, використання технологій інформаційного суспільства в організації управлінського процесу, знищення корупџійних «пасток» у системі надання послуг населенню та ін.

Аргументується, щзо популяризація електронного урядування здатна стати успішною при вмілій доступній подачі інформащії. В епоху інформаційного суспільства з'явилися нові можливості для популяризації практик електронного врядування: через мас-медіа, сочіальні мережі, сочіальну рекламу тощо.

Обтрунтовується, що популяризація електронного врядування серед населення здатна стати запорукою успішності процесу демократизації, оскільки иее сприятиме формуванню демократичної політичної культури суспільства, основою якої $\epsilon$ культивування довіри, консолідації, толерантності тощзо.

Ключові слова: електронне урядування, демократизація, політична культура, популяризація, демократична політична культура, Україна.

\section{ПОПУЛЯРИЗАЦИЯ ЭЛЕКТРОННОГО ПРАВИТЕЛЬСТВА В УКРАИНЕ КАК ЗАЛОГ ЭФФЕКТИВНОГО ПРОЦЕССА ДЕМОКРАТИЗАЦИИ: ПОЛИТИКО-КУЛЬТУРНЫЙ РАКУРС}

\author{
Б.Ю. Куц
}

Статья посвящена выявлению специфики популяризации электронного управления в Украине. Отмечается, что важным компонентом электронного управления является электронная демократия, благодаря которой возникает возможность избежать излишней бюрократизации в системе органов власти, приближения власти к гражданам путем удовлетворения их потребностей, использования технологий информационного общества в организачии управленческого процесса, уничтожения коррупщионных «ловушек» в системе предоставления услуг населению и др.

Аргументируется, что популяризащия электронного управления способна стать успешной при умелой доступной подачи информации. В эпоху информационного общества появились новые возможности для популяризации практик электронного управления: через СМИ, социальные сети, сочиильную рекламу и т.n.

Обосновывается, что популяризация электронного управления среди населения способна стать залогом успешности процесса демократизации, поскольку это будет

(C) Б.Ю. Куц, 2019 
способствовать формированию демократической политической культуры общества, основой которой является культивирование доверия, консолидации, толерантности и др.

Ключевые слова: электронное управление, демократизация, политическая культура, популяризачия, демократическая политическая культура, Украина.

\section{POPULARIZATION OF ELECTRONIC GOVERNANCE IN UKRAINE AS A GUARANTEE FOR THE EFFICIENCY OF THE DEMOCRATIZATION PROCESS: A POLITICAL AND CULTURAL ASPECT}

\section{B. Kuts}

The article is devoted to revealing the features of popularizing e-government in Ukraine among the population as a guarantee of the effectiveness of the democratization process in the political and cultural context.

The effectiveness of e-government implementation depends on many factors, the basic of which is the correlation of this process with key principles of political culture. For the democratic political culture of society, such qualities as trust, responsibility, respect for the others, morality, honesty, etc. are of great importance. The cornerstone of a democratic political regime is the rule of law and, accordingly, the respect of individuals for the law. The concepts of openness and transparency in the exercise of power are of great importance for the success of democratization. After all, the "closeness" of the authorities determines the lack of confidence in the authorities' decisions on the part of the citizens.

In the processes of popularizing e-governance among the population, PR (Public Relations) technologies are becoming more and more important.

It is argued that the promotion of e-government can benefit from the experience of incorporating democratic values into the mass consciousness of US citizens. In the eighteenth century well-known politicians published articles of a liberal-democratic nature explaining the priorities of the future Constitution in a very accessible form in order to ratify the US Constitution. Nowadays, in the age of the information society, new opportunities have emerged to promote e-governance practices in a defined way: through the media, social networks, social advertising, and more.

It is noted that an important component of e-governance is e-democracy, due to which there is a possibility of avoiding excessive bureaucracy in the system of authorities, bringing authorities closer to citizens by meeting their needs, using information society technologies in the organization of administrative process, eliminating corruption "traps" in the system of providing services to population, etc.

The popularization of e-government among the population can significantly reduce the level of political nihilism of citizens, which will give them additional opportunities for optimal interaction with the authorities. In addition to simplifying procedures for citizens regarding the availability of information about government activities, the government itself will be able to obtain an additional flow of information voluntarily provided by citizens to improve public administration.

In general, the popularization of e-government among the population can be the key to the success of the democratization process, since it will contribute to the formation of a democratic political culture of a society based on the cultivation of trust, consolidation, tolerance and so on.

Keywords: e-governance, democratization, political culture, popularization, democratic political culture, Ukraine. 
Постановка проблеми. Проблематика електронного урядування, підвищення рівня обізнаності населення в означеній сфері у контексті процесів формування демократичної політичної культури набуває актуальності для політичного простору України. На важливості формування відкритості та прозорості держави перед громадянами наголошується у Доктрині інформаційної безпеки України. Зазначається, що серед пріоритетів державної політики в інформаційній сфері $\epsilon$ «розвиток механізмів електронного урядування; сприяння розвитку можливостей доступу та використання публічної інформації у формі відкритих даних; інформування громадян України про діяльність органів державної влади, налагодження ефективної співпраці зазначених органів із засобами масової інформації та журналістами; проведення реформи урядових комунікацій; розвиток сервісів, спрямованих на більш масштабне та ефективне залучення громадськості до прийняття рішень органами державної влади та органами місцевого самоврядування; сприяння формуванню культури суспільної дискусії» (Законодавство України, 2017). Разом з тим, впровадження електронного урядування в Україні доволі часто наштовхується на перепони через недостатній рівень обізнаності населення з його можливостями.

Аналіз актуальних досліджень. Проблематика електронного урядування, його впливу на процеси демократизації активно досліджується в політологічному, соціально-філософському, державно-управлінському дискурсах (Д. Белл, В. Бех, М. Вершинін, О. Голобуцький, М. Демкова, О. Додонов, П. Дракер, Дж.-А. Еноксен, О. Смельяненко, М. Кастельс, П. Клімушин, К. Кросс, О. Кудрявцев, У. Ліппман, Й. Масуда, А. Митко, Дж. Нейсбіт, С. Пономарьов, Г. Почепцов, . Проскуріна, А. Серенок, А. Сіленко, О. Соснін, О. Титаренко, Е. Тоффлер, А. Турен, Т. Фрідман, Ф. Фукуяма, С. Чукут, О. Шевчук та ін.).

Метою статті стало виявлення специфіки впровадження електронного урядування в контексті процесу демократизації. Завдання статті полягає у виявленні політико-культурних аспектів популяризації електронного 
урядування в Україні серед населення як запоруки ефективності процесу демократизації.

Виклад основного матеріалу. В останні роки в Україні активно проходить впровадження електронного урядування для переходу до комп'ютеризованого виду діяльності державних інституцій. Урядом було схвалена Концепція розвитку електронного урядування в Україні, в якій було визначено напрями, механізми та строки формування системи електронного урядування.

Під електронним урядуванням мається на увазі «форма організації державного управління, яка сприяє підвищенню ефективності, відкритості та прозорості діяльності органів державної влади та органів місцевого самоврядування 3 використанням інформаційно-телекомунікаційних технологій для формування нового типу держави, орієнтованої на задоволення потреб громадян» (Урядовий портал, 2017).

Централізовано у провідних країнах світу процес впровадження елементів електронного уряду в управлінську структуру держави розпочався з 2000 р.. Саме тоді була прийнята Окінавська хартія країнами «великої вісімки», згідно з якою уряди країн-учасниць були зобов'язані сприяти впровадженню інформаційно-комунікативних технологій на різних рівнях державного управління. Крім того, ставилася умова стосовно забезпечення суспільств рівними та доступними можливостями у використанні інформаційних ресурсів усіх видів (Кудрявцев, 2016).

Як зазначає С. А. Чукут (2016), «сутність електронного урядування полягає не лише в тому, що воно являє собою модернізацію системи державного управління, адаптацію їі до потреб інформаційного суспільства, але й передбачає насамперед взаємодію громадян з владою за допомогою сучасних інформаційно-комунікативних технологій».

Ефективність упровадження електронного урядування залежить від багатьох факторів, базовим із яких є кореляція цього процесу з ключовими принципами політичної культури. 
Тип політичної культури безпосередньо впливає на поведінку людей та напрям діяльності організацій різних типів, на їх сприйняття подій у внутрішній та зовнішній політиці, якість оцінки політичних систем та режимів, правлячих груп і окремих політичних осіб, а також на визначення громадянином свого місця в політичному житті суспільства (Куц, 2007, 2011). Політична культура суспільства визначає специфіку політичного прогнозування, прийняття та реалізації конкретних політико-управлінських рішень, розробки політичного курсу певного соціуму. Стан політичної культури має велике значення, оскільки від нього залежить якість діалогу влади з громадою, під час якого можна дізнатися про ставлення населення до політичного курсу, що розробляється. Саме під час комунікації на рівні «влада-громада» можна виявити чи позитивне ставлення громадян до влади, чи воно байдуже, погодиться населення 3 існуючим політичним курсом добровільно чи буде проявляти опір та ворожість (а також буде цей опір пасивний чи активний). Стеження за ступенем зрілості $\mathrm{i}$ характером політичної культури дозволяє передбачити реакцію населення на прийняте політико-управлінське рішення, спланувати певні заходи, що забезпечать вірну підготовку рішення і його ефективну реалізацію.

Процес демократизації можна вважати ефективним, якщо доброчесність буде вважатися домінантною ознакою політичної культури суспільства. За таких умов, вважав Ш.-Л. Монтеск'є, буде забезпечена стійкість влади, оскільки вона не в останню чергу залежить від тих ключових ознак, що найбільш поширені у масовій свідомості підвладних. Теоретик виділяв три форми правління: республіка (сюди відносяться два їі підвиди: демократія та аристократія), монархія та деспотія. Задля успішного управління, вважав Ш.-Л. Монтеск’є, слід культивувати певні риси у підвладних: доброчесність - для демократії; поміркованість - для аристократії; честолюбство - для монархї; страх - для деспотії (1955, с. 179185). Для демократичної політичної культури суспільства вагомого значення 
набувають такі якості як довіра, відповідальність, повага до іншого, моральність, чесність та ін.

Наріжним каменем для демократичного політичного режиму $\epsilon$ верховенство права. За таких умов, коли у суспільстві пріоритетом стає повага до закону, більш ефективно забезпечується легітимність влади. Закон - це нормативно-правовий акт, який приймається щодо значимих питань i проблем суспільного, державного життя і має вищу юридичну силу. Закон найчастіше приймається вищим представницьким органом держави (парламентом) або на референдумі. Відповідно, закон є проявом державного суверенітету. Закон, будучи самостійним джерелом права, з’явився ще в стародавні часи, прийшовши на заміну правовому звичаю. Прийнято виокремлювати дві традиції розвитку закону (європейська і східна), які відрізняються розумінням верховенства закону. Для Європи характерна світська концепція закону. Для Сходу притаманне або релігійне трактування закону (наприклад, іслам), або це поняття до появи там європейців взагалі було відсутнє (індуїзм та ін.). У наш час дискусії в розумінні поняття «закон» найчастіше відбуваються між адептами теорії «правового позитивізму» i адептами теорії природного права. Найбільш гострі суперечності виникають у сфері співвідношення закону і моралі. Позитивісти чітко розділяють ці поняття, тоді як теоретики природного права вважають, що між законом i мораллю не повинно бути сильних розбіжностей. Разом 3 тим, теоретики поділяють думку, що поняття законності та демократії корелюють між собою.

Дотримання закону призводить до порядку як забезпечення за допомогою використання певних соціально-економічних важелів стабільності суспільно-політичного розвитку. Поняття порядку в суспільнополітичному дискурсі чітко співвідноситься 3 поняттям стабільності. Саме тому концепт порядку є базисним для ідеології консерватизму, основою якої є опора на традиційність і стабільність суспільних підвалин. Разом з тим, слід зазначити, що поняття стабільності вже давно вимагає масштабного 
переосмислення у політико-управлінському дискурсі. Цікавою в цьому контексті - як зразок практичного втілення - $є$ ідеологія ордолібералізму (від лат. поняття «оrdo» - порядок). Термін виникнув у Фрайбурзькій школі неолібералізму, яку заснував В. Ойкен (Німеччина). В. Ойкен пропагував концепцію ордолібералізму, маючи на увазі впровадження соціального ринкового господарства (Ойкен, 1995). На його думку, держава не повинна втручатися в економічні процеси. Натомість, функцією державних владних органів є створенні інституційних механізмів для регулювання економіки, що спрямовані проти іiі монополізації. Практичне впровадження ордоліберального ідей - так зване «німецьке чудо» - здійснилося з приходом Л. Ерхарда на посаду канцлера повоєнної Німеччини.

Питання формування політичної грамотності населення стосовно пріоритетів електронного урядування $\epsilon$ особливо важливим в умовах європейської інтеграції. Маючи недовготривалий період після проголошення незалежності, Україна зіштовхується зі складнощами при вирішенні цих завдань. За відсутності чітких державно-управлінських механізмів у процесі формування системи електронного урядування в Україні відбувається запозичення і перенесення досвіду та практик з країн Заходу. Цей досвід, хоча i має велике значення для України i певні його елементи можуть виявитися корисними, в умовах незвичного соціокультурного контексту є не завжди достатньо застосовним.

Для успішності демократизації вагомого значення набувають концепти відкритості та прозорості у процесі здійснення влади. Як слушно зазначав Є. Бентам, перевага «гласності полягає в тому, що вона гарантує довіру народу та його згоду на законодавчі заходи» (Бентам, 2006). Тобто, «закритість» влади детермінує недовіру до владних рішень з боку громадян.

В означеному контексті, популяризація електронного урядування серед населення сприятиме забезпеченню відкритості та прозорості влади, піi транспарентності (Куц ред., 2011, 2013). А транспарентність владних органів - це ознака руйнування корупційних схем. 
У процесах популяризації електронного врядування серед населення вагоме знамення набувають технології PR (Public Relations). Походження терміну PR «Паблік рілейшнз» пов' язують з Томасом Джесрерсоном (автором американської Декларації незалежності), який вперше використав це словосполучення на початку XIX ст. На його думку, PR - це «нарощування зусиль політичних інститутів для створення клімату довіри в національному масштабі» (Кізь, 2014, с. 375).

Отже, у розумінні сутності PR вагому роль відіграє поняття довіри. I це важливо, оскільки ефрективність співпраці між індивідами залежить від довіри між ними. Адже довіра $є$ основою соціального капіталу. Як зазнамав Ф. Фукуяма, під соціальним капіталом мається на увазі «набір недрормальних цінностей чи норм, які розділяються членами групи і які роблять можливою співпрацю всередині цієї групи» (Фукуяма, 2003, с. 30). До цінностей, що здатні сприяти появі соціального капіталу відносять правдивість, співпрацю 3 іншими, виконання взятих на себе зобов' язань i, звісно, довіру (Фукуяма, 2003, c. 31).

Задля ведення просвітницьких заходів щодо популяризації електронного врядування можна скористатися досвідом втілення демократичних цінностей у масову свідомість громадян США. 3 метою необхідності ратифікації Конституції США у XVIII ст. відомі політики публікували статті ліберально-демократичного характеру у вельми доступній формі, роз'яснюючи пріоритети майбутньої Конституції. Ці статті O. Гамільтон, Дж. Джей та Дж. Медісон публікували під псевдонімом (Яковлева ред., 1994). Тобто, популяризація навіть настільки серйозних речей як Конституція, здатна стати успішною при вмілій доступній подачі інформації. У наш час - в епоху інформаційного суспільства - 3'явилися нові можливості для популяризації означеним способом практик електронного врядування: через мас-медіа, соціальні мережі, соціальну рекламу тощо (Безрук, 2017; Данько, 2015; Денисенко, 2015 ). 
Висновки i перспективи подальших досліджень. Таким чином, важливою компонентою електронного урядування є електронна демократія, завдяки якій постає можливість уникнення надмірної бюрократизації в системі органів влади, наближення влади до громадян шляхом задоволення їхніх потреб, використання технологій інформаційного суспільства в організації управлінського процесу, знищення корупційних «пасток» у системі надання послуг населенню та ін.

3 доступністю електронного урядування зростає потреба політичної грамотності населення. Згідно 3 Конституцією, саме народ $\epsilon$ носієм суверенітету і єдиним джерелом влади в Україні. При недемократичних типах політичної культури у суспільстві зростає рівень недовіри до влади, що детермінує низьку політичну активність індивідів. За умов формування демократичної політичної культури постає проблема розуміння громадянами політичних процесів національного державотворення та важливості участі в цих процесах.

Популяризація електронного врядування серед населення здатна призвести до значного зниження рівня політичного нігілізму громадян, що надасть їм додаткових можливостей для оптимальної взаємодії з органами влади. Окрім спрощення процедур для громадян стосовно доступності інформації про діяльність уряду, сам уряд зможе отримати додатковий потік інформації, добровільно наданої громадянами для удосконалення державного управління.

У цілому, популяризація електронного врядування серед населення здатна стати запорукою успішності процесу демократизації, оскільки це сприятиме формуванню демократичної політичної культури суспільства, основою якої є культивування довіри, консолідації, толерантності тощо.

\section{ЛІТЕРАТУРА}

1. Безрук, О. О., 2017. Політична участь як чинник політичної мобілізації: теоретичний аспект. Сучасне суспільство: політичні науки, соџіологічні науки, культурологічні науки, 1 (13), с. 16-24. 
2. Бентам, И., 2006. Тактика законодательных собраний. Перевод с английского Л.А. Велихов. Челябинск : Социум.

3. Данько, Ю. А., 2015. Астротурфінг як інструмент віртуальної маніпуляції та політичної пропаганди в умовах інформаційної доби. Сучасне суспільство: політичні науки, соціологічні науки, культурологічні науки, 2 (8), Ч. 1, с. 38-49.

4. Денисенко, І. Д., 2015. Моделювання поведінки особистості в сучасних соціокультурних контекстах: методологічні засади та перспективи. Вісник ХНПУ імені Г. С. Сковороди «Філософія», 45 (1), с. 205-214.

5. Законодавство України, 2017. Про рімення Ради наџіональної безпеки $і$ оборони України від 29 грудня 2016 року «Про Доктрину інформаційної безпеки України». [online] (Останне оновлення 25 Лютий 2017) Доступно: https://zakon.rada.gov.ua/laws/show/47/2017 [Дата звернення 5 Вересень 2019].

6. Кізь, М. В., 2014. Соціальна діяльність і політичний PR. Гілея: науковий вісник, 86 (7), с. 374-378.

7. Кудрявцев, О.Ю., 2016. Електронне урядування у сучасному політикоадміністративному просторі: монографія. Харків: ХНУМГ ім. О. М. Бекетова.

8. Куц, Ю. О. ред., 2011. Територіальна громада: знаннєвість, дієвість: монографія. Харків: ХарРІ НАДУ: Апостроф.

9. Куц, Ю. О. ред., 2013. Територіальна громада: управління розвитком: монографія. Харків: Константа.

10. Куц, Г. М., 2007. Проблематика ідентичності в ліберальному контексті. Вісник Харківського національного університету імені В.Н.ККаразіна. «Питання політологї̈, 785 (10), с. 79-85.

11. Куц, Г. М., 2011. Трансформаційний потенціал лібералізму в політичному просторі. Доктор наук. Чернівецький національний університет імені Юрія Федьковича.

12. Монтескье, Ш.-Л., 1955. Избранные произведения. Перевод с французского. Москва: Государственное издательство политической литературы.

13. Ойкен, В., 1995. Основные принципы экономической политики. Перевод с немецкого Л. А. Козлова и Ю. И. Куколева. Москва : Прогресс-Универс.

14. Урядовий портал, 2017. Про схвалення Конщеецї розвитку електронного урядування в Україні. [online] Доступно: https://www.kmu.gov.ua/ua/npas/250287124 [Дата звернення 5 Вересень 2019].

15. Фукуяма, Ф., 2003. Великий разрыв. Перевод с английского А. В. Александровой. Москва: ООО «Издательство АСТ».

16. Чукут, С. А., 2016. Тенденції та проблеми впровадження електронного урядування в Україні. [online] Доступно: http://ktpu.kpi.ua/wpcontent/uploads/2016/02/Tezi_Tendentsiyi-ta-problemi-vprovadzhennya-elektronnogouryaduvannya.pdf.

17. Яковлева, Н. Н. ред., 1994. Федералист. Политические эссе А. Гамильтона, Дж. Мэдисона и Дж. Джея. Перевод с английского Н. Яковлева, М. Шерешевской, Э. Осиповой. Москва : Издательская группа «Прогресс» - «Литера».

\section{Інформація про автора}

Куц Богдан Юрійович - магістрант факультету публічного управління та адміністрування Харківського регіонального інституту державного управління Національної академії державного управління при Президентові України; e-mail: kuts.bogdan.a@gmail.com; ORCID: https://orcid.org/0000-0002-9009-3970.

Стаття надійшла до редакції: 01.11.2019 р. $\quad$ Прийнята до друку: 20.11.2019 p. 